Variations sur la lettre, le mètre et la mesure :

Shakespeare

\title{
Brutus's dog-eared book in Julius Caesar
}

\section{Maurice Charney}

\section{(2) OpenEdition \\ 12 Journals}

\section{Electronic version}

URL: http://journals.openedition.org/shakespeare/979

DOI: $10.4000 /$ shakespeare. 979

ISSN: 2271-6424

Publisher

Société Française Shakespeare

\section{Printed version}

Date of publication: 1 November 1996

Number of pages: 139-150

\section{Electronic reference}

Maurice Charney, "Brutus's dog-eared book in Julius Caesar », Actes des congrès de la Société française Shakespeare [Online], 14 | 1996, Online since 01 January 2007, connection on 01 May 2019. URL:

http://journals.openedition.org/shakespeare/979; DOI : 10.4000/shakespeare.979 


\section{Variations sur la lettre,}

le mètre et la mesure

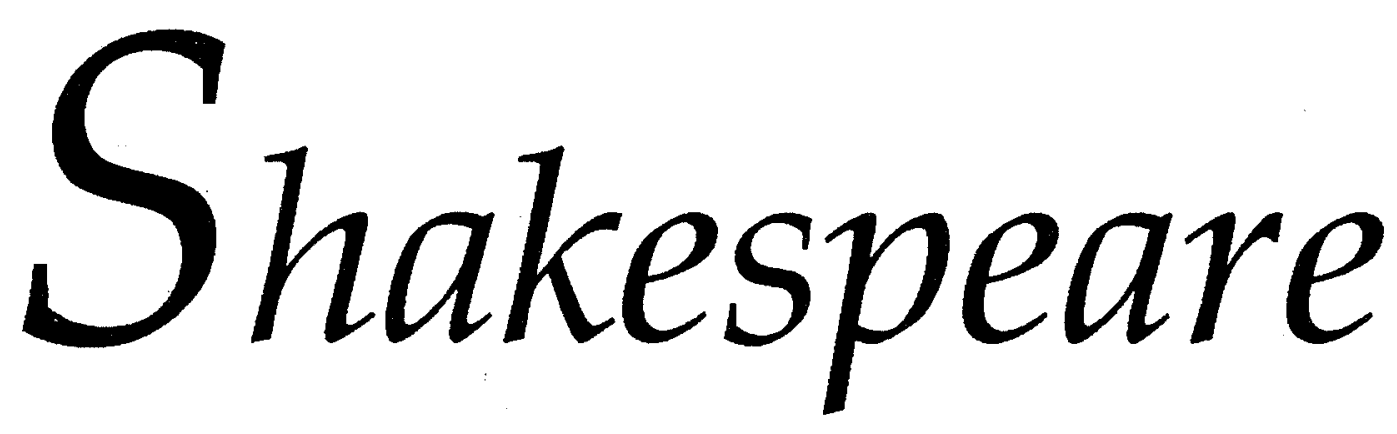

textes présentés par Dominique Goy-Blanquet

Directeur de la publication : Richard Marienstras 


\section{Brutus's dog-eared book in Julius Caesar}

At the end of the quarrel scene between Brutus and Cassius in Act IV of Julius Caesar, when everyone has left the stage except Brutus and the boy Lucius, his household servant, Brutus is represented in a very personal and intimate way. Lucius brings him his "gown", a warm dressing gown intended to protect a sleeper, or soon-to-be sleeper, against the cold and damp night air. The sleepless Brutus also appears in his gown in the orchard scene of Act II, when he meets the conspirators and agrees to participate in the conspiracy. Portia, who will not be put off by her husband's feeble excuses, provides the meteorological detail :

Is Brutus sick, and is it physical

To walk unbracèd and suck up the humours

Of the dank morning? What, is Brutus sick, And will he steal out of his wholesome bed,

To dare the vile contagion of the night,

And tempt the rheumy and unpurgèd air

To add unto his sickness?

It is obvious that Shakespeare is thinking of the rheumy and unpurgèd air and the dank mornings of England in early spring rather than of ancient Rome. Cæsar, too, when he awakes in the midst of thunder and lightning in the next scene, enters "in his nightgown". The melancholy mood at the end of the quarrel scene in Act IV thus recalls the anxious tone of the orchard scene in Act II with all its forebodings of ill.

Shakespeare makes significant efforts to humanize Brutus in the quarrel scene, to represent him as a tender, caring person. Like the mad Lear and his Fool, Brutus shows a fatherly concern about the boy Lucius, who is sleepy to the point of exhaustion. When Brutus asks him about his instrument, presumably the lute with which he will accompany himself in his song, Brutus is struck by the boy's reply : "What, thou speakest drowsily ? / Poor knave, I blame thee not; thou art o'erwatched" (IV.3.239-40).

This is very different from Brutus's imperious and supercilious tone with Cassius earlier in the scene. Brutus was haughty and morally superior in a way so irritating that Cassius was almost provoked to draw his sword and stab him. Brutus, for example, establishes his own high-mindedness by a speech calculated to infuriate Cassius : 


\begin{abstract}
What, shall one of us
That struck the foremost man of all this world

But for supporting robbers, shall we now

Contaminate our fingers with base bribes, And sell the mighty space of our large honours

For so much trash as may be graspèd thus?
\end{abstract}

(IV.3.21-6)

The contemptuous gesture that accompanies "graspèd thus" to indicate Brutus's superiority to mere cash, really stings Cassius :

\author{
Brutus, bait not me; \\ I'll not endure it. You forget yourself \\ To hedge me in.
}

Cassius is right to think that his noble friend is baiting him, and this infuses the quarrel scene with passionate and strongly contradictory emotions.

More than two hundred lines of intense and unpredictable emotions precede the moment when Brutus is alone on stage with Lucius. He calls the soldiers Varro and Claudius to come and "sleep on cushions in my tent" rather than "stand and watch"; Brutus will wake them when he has business "to my brother Cassius" (IV.3.242-48). Why is Shakespeare at such pains to represent Brutus's kindly, human concerns at this moment ? It is all a calculated part of the context for the appearance of Cæsar's Ghost, which more or less seals the doom of the conspirators. When Varro and Claudius lie down on cushions in Brutus's tent, we have another surprising domestic detail : "Look, Lucius, here's the book I sought for so; / I put it in the pocket of my gown" (251-52). This is a wild anachronism for ancient Rome, like the striking clocks that bothered eighteenth century editors, since Shakespeare seems to be thinking of the familiar, bed-time reading of the Elizabethans rather than the papyrus scrolls of the Romans. Was Shakespeare so abysmally ignorant of Roman history that he did not know Brutus could not have a printed book in the pocket of his dressing gown or hear clocks striking the hour actually 3 a.m. (II.1.191 s.d.) - in Cæsar's Rome ? I agree with Sigurd Burckhardt in his teasing essay, "How Not to Murder Cæesar", that Shakespeare "did know that he was committing an anachronism", with all of its ironic and paradoxical consequences ${ }^{1}$.

To return to the quarrel scene, there is an overflowing of affective details about Brutus's tenderness and human concerns. He is extremely solicitous about Lucius and his physical condition in a way that occurs with no other character in the play, not even Portia. His request for music is remarkably polite :

Canst thou hold up thy heavy eyes awhile, And touch thy instrument a strain or two?

(IV.3.255-56) 
Brutus continues with almost exaggerated deference for a servant: "I trouble thee too much, but thou art willing" (258) and "I should not urge thy duty past thy might; / I know young bloods look for a time of rest" (260-61). Before the song, Brutus says cryptically: "If I do live, / I will be good to thee" (264-65). We know from remarks like these in Shakespeare's tragedies that Brutus senses his imminent death. The uncertainty about living on is part of the elegiac mood of the last two acts of the play. The conspirators talk constantly of death, they anticipate death, and they elaborate Stoic strategies for dealing with their inevitable doom.

Strangely enough, Lucius falls asleep in the midst of his accompanied song. We do not have, alas, the text of his "sleepy tune", but Brutus shows an amazing paternal concern for Lucius - he has no children of his own that we know of in the play. He wishes the boy good night and takes his instrument out of his hands :

Gentle knave, good night;

I will not do thee so much wrong to wake thee.

If thou dost nod thou break'st thy instrument;

I'll take it from thee; and, good boy, good night.

(IV.3.268-71)

It is at this moment that we have another amazingly personal detail that lies outside the scope of official Roman history. Brutus takes the book out of the pocket of his gown and tries to find his place - all of these details represent him as an inveterate bed-time reader :

Let me see, let me see; is not the leaf turned down Where I left reading? Here it is, I think.

(IV.3.272-73)

So it turns out that this is a dog-eared book that Brutus is handling and he is able to find the place "Where I left reading."

The thickness of personal and domestic detail provides a brilliant Shakespearean aura for the appearance of the Ghost of Cæesar. The worldly is obviously emphasized as a bulwark against the otherworldly. We see three sleeping figures on stage in Brutus's tent - Varro, Claudius, and Lucius - but only Brutus is awake. The immediate sign of the ghost is that Brutus's taper burns ill, presumably blue. Despite his fear and wonder at this "monstrous apparition" (276), Brutus is intrepid, and he interrogates the Ghost in a way that clearly anticipates Hamlet :

Art thou some god, some angel, or some devil, That mak'st my blood cold, and my hair to stare?

(IV.3.278-79)

The supernatural is conceived in Flizabethan and Christian terms so that the ghost is ambiguous : either angelic or diabolic. The Ghost comes with a message of doom : 
"thou shalt see me at Philippi" (282), implying, of course, that the conspirators face certain defeat in battle, but Brutus insists on fighting at Philippi even when Cassius wisely demurs. Like Hamlet, Brutus shows himself vis-à-vis the Ghost as an unsatisfied intellectual. He is disappointed and frustrated at the fact that the Ghost can just break off the discourse at will :

Now that I have taken heart thou vanishest. Ill spirit, I would hold more talk with thee.

(IV.3.286-87)

"Ill spirit" sounds like a personal affront, since Brutus is no longer wondering "Art thou some god, some angel, or some devil".

All of the personal details lavished on Brutus in the quarrel scene develop his tragic stature. In this early tragedy, Shakespeare is much more successful than he was in Titus Andonicus and Romeo and Juliet in manipulating audience response to create a strong feeling of catharsis. Cassius, for example, is deliberately deprived of the strong currents of feeling we have for Brutus. In the early part of the play Cassius was seen as a Malcontent, unhappy at Cæsar's preeminence and envious of his good fortune. Cassius's soliloquy at the end of Act I, scene 2 , is very much like the villain's characteristic scene-ending declaration of purpose. He expresses his contempt for the gentle and soft-tempered Brutus who is easy to flatter, like Cæsar himself ${ }^{2}$. The principle behind this soliloquy is embodied in the question : "For who so firm that cannot be seduced ?" (I.2.312) - not persuaded, but seduced. We catch only a glimpse of Cassius as a person in the quarrel scene, when he apologizes for his waspish, choleric temperament :

Have you not love enough to bear with me

When that rash humour which my mother gave me

Makes me forgetful?

(IV.3.118-20)

This is touching but excessively brief, and we feel that Cassius here and everywhere else is too ready to defer to Brutus's bad and non-political judgment. There is plenty of engaging detail about Cassius in Plutarch that Shakespeare chooses not to use, for example, the fascinating account of Cassius's pet lions.

Antony, too, is presented in Julius Caesar without the rich personal detail that plays such a significant role in Antony and Cleopatra. He is presumably one of those "sleek-headed" and "fat" men that "sleep a-nights" (I.2.192-93) that Cæsar likes to have about him, gamesome and a lover of sport unlike Cassius, who "has a lean and hungry look; / He thinks too much : such men are dangerous" (194-95). Antony does not have a reputation of thinking too much. He is first seen in the play naked (or close to it), ready for the race that was part of the Lupercalian games. Casar superstitiously believes in Antony's super-potency because he asks him to touch Calphurnia while he is running in order to cure her of her "sterile curse" (9). 
The word "touch" has a strong undercurrent of sexual innuendo, as in the "abominable and beastly touches" by which Pompey the bawd lives ${ }^{3}$.

If Antony is left fairly blank in the play, Casar is endowed with the kind of personal details that we have seen in Brutus, except that these details are either ambiguous or negative. The passage we have just quoted about Antony suggests that Cæsar himself may be sterile or impotent. Later we learn from Cassius that in their swimming match, Cæsar almost drowned and had to be carried from the Tiber by the triumphant Cassius. Also that Cæsar had a fever in Spain, that "this god did shake" (I.2.121), and that he cried out "As a sick girl, 'Give me some drink, Titinius'"127-28). Shakespeare invents most of these derogatory details, which he did not find in his sources, including the fact that Casar has the "falling sickness", or epilepsy. His casual statement to Antony comes as a bombshell to the audience : "Come on my right hand, for this ear is deaf" (213). It is hard to believe that the great Cæesar will actually become king or emperor or that he can possibly live very long. His godlike pretensions are seen to be hollow when set against his physical infirmities.

One other figure in the play is presented as a real counterpart to Brutus in warmth and intimacy of characterization and that is Brutus's wife, Portia. She is a remarkable character in Shakespeare's development, since she eventually and tragically shares Brutus's secrets (while Kate emphatically does not share Hotspur's in the first part of Henry IV). In the orchard scene, the boy Lucius is "fast asleep" (as he is again in the quarrel scene) after the conspirators leave and Brutus is alone on stage, now fully won over to the cause of the conspirators. With the entrance of Portia at line 233, the tide turns from political to personal concerns. Brutus is once again the troubled, sleep-deprived figure in his dressing gown that he was at the beginning of the scene :

Between the acting of a dreadful thing And the first motion, all the interim is Like a phantasma, or a hideous dream.

In the assured ethical posture of a Roman matron, Portia takes a strong personal tone with her husband: "Y'have ungently, Brutus, / Stole from my bed" (237-38). Not your bed or our bed, but my bed. Portia simply will not accept Brutus's homely gestures of impatience : his scratching his head, his querulous stamping with his foot, the "angry wafter" of his hand. The personal details set up an important domestic confrontation.

Portia knows that her husband has "some sick offense" within his mind and she kneels to him to hear about it. But the point is that she is not a subservient confidante but a peer in marriage, fully entitled to share her husband's secrets, "Which by the right and virtue of my place / I ought to know of" (269-70). This is a remarkable speech because it attempts to define the nature of a companionate marriage. If she is only there "To keep with you at meals, comfort your bed, / And talk to you sometimes", then "Portia is Brutus's harlot, not his wife" (284-87). We are 


\section{BRUTUS'S DOG-EARED BOOK}

cheering Portia on from the feminist sidelines. Brutus's reaction to all of this affective pleading makes for one of the most poetic passages in an otherwise restrained play :

You are my true and honourable wife, As dear to me as are the ruddy drops

That visit my sad heart.

(II.1.288-90)

The "ruddy drops" are not the imperial purple but the colour of real blood, and we are touched by Brutus's personal, slightly awkward Roman style.

The climax of this scene is in Portia's Stoic declaration :

I have made strong proof of my constancy, Giving myself a voluntary wound

Here in the thigh; can I bear that with patience, And not my husband's secrets?

(II.1.299-302)

Even if Portia was played by an adolescent boy actor, the showing of her voluntary wound in the thigh, like Coriolanus's showing of his wounds when he solicits the plebeians' votes, would have an extraordinary effect not only on Brutus but also on the audience. This exhibitionism is part of the buried sexual spectacle in the play. Portia's wound is an irresistible demonstration of devotion, and Brutus is firmly won over: "O ye gods, / Render me worthy of this noble wife !" (302-3).

When we next see Portia, in Act II, scene 4, she is already extremely agitated and overwrought by what she knows of the conspiracy. This is a bad sign, and this is the last we see of her in the play. We do not discover her tragic fate until the quarrel scene, which turns very specifically on her death. The scene is brilliantly organized around a striking peripeteia at the centre. Brutus has been smug and supercilious with his friend Cassius, who is rapidly losing patience. But then the quarrel seems to abate as Brutus turns melancholy and confesses to his personal weakness :

O Cassius, you are yokèd with a lamb

That carries anger as the flint bears fire, Who, much enforcèd, shows a hasty spark, And straight is cold again.

What is really perturbing Brutus comes out suddenly some thirty lines later: "No man bears sorrow better. Portia is dead" (146). So the death of Portia hovers over the quarrel scene and shapes its affective reality.

Shakespeare follows Plutarch closely here in his account of Portia's suicide by swallowing hot coals. Thus the revelations that Portia so actively solicited prove to be fatal for her. We have a second revelation of Portia's death from Messala later 
in the scene, but this is anticlimactic and may have been marked for deletion. The second time around, Brutus's reaction seems perfunctory :

Why, farewell, Portia. We must die, Messala.

With meditating that she must die once,

I have the patience to endure it now.

(IV.3.189-91)

In relation to the eloquent statements about death at the end of the play, this seems like a collection of Stoic clichés.

Having thus registered the distribution of personal, humanizing details in Julius Casar, especially in relation to Brutus and Portia, it is necessary to point out exactly the opposite tendency in the play : the kind of grave formality associated with the Roman style and the sense of abstraction and theoretical commitment in Brutus and the conspirators. In his funeral eulogy for Brutus, Antony has a good sense of Brutus's detachment from ordinary life. He was "the noblest Roman of them all" because he was not impelled by personal motives but "only in a general honest thought / And common good to all, made one of them" (V.5.71-2). This is certainly not true of Cassius or any of the other conspirators. We see Shakespeare pursuing a Pirandellesque idea in representing Brutus personally and impersonally at the same time, as if "il sentimento del contrario" - Pirandello's "feeling of the opposite" - could naturally explain the contradictions in Brutus and in the play.

Brutus's inclination to the histrionic is a fascinating topic. Of course we can find self-conscious allusions to the theatre and to acting everywhere in Shakespeare, but in Julius Casar they go to the heart of the play because Brutus conceives of the conspiracy itself as a theatrical spectacle. It is notable how both Brutus and Othello reject the idea of bloody murder and fasten on the killing of their victim as a highly staged, purified, hieratic, priestly sacrifice. Brutus uses those very words to sketch the scenario of the assassination to Cassius. Having emphatically rejected the killing of Antony,

Our course will seem too bloody, Caius Cassius, To cut the head off and then hack the limbs ...

(II.1.162-63)

he proceeds to impart his vision of the scene as if it were the film version of a religious ritual :

Let's be sacrificers but not butchers, Caius.

We all stand up against the spirit of Casar, And in the spirit of men there is no blood.

$O$, that we then could come by Casar's spirit, And not dismember Casar! But, alas, Casar must bleed for it. 
This does not sound like a professional murderer ready to kill off his victim, like the paid assassins in Macbeth or Richard III.

Of course, Brutus's well-meaning project bears little relation to the actual killing of Cæsar, which is unusually bloody, since each of the conspirators is required to stab Cæsar separately. If Brutus is indeed the last, then we see him stab an almost lifeless body already sufficiently mangled and bloody from myriad other wounds. Brutus is the one who calls for all of his fellows to "bathe our hands in Cæsar's blood / Up to the elbows, and besmear our swords" (III.1.106-7). If the stage action observes this ghastly ritual literally, all of the conspirators are marked with Cæsar's blood up to the elbows. This is a point that the calculating Antony drives home to them: "Now, whilst your purpled hands do reek and smoke, / Fulfill your pleasure" (158-59), and "Let each man render me his bloody hand" (185), and

Pardon me Julius! Here wast thou bayed, brave hart;

Here didst thou fall, and here thy hunters stand,

Signed in thy spoil and crimsoned in thy lethe.

(III.1.204-6)

In his soliloquy after the conspirators have left the stage, Antony goes so far as to play on Brutus's word "butchers":

$O$, pardon me, thou bleeding piece of earth, That I am meek and gentle with these butchers!

(III.1.254-55)

What could Brutus possibly be thinking that he is so eager for the conspirators to mark themselves in Cæsar's blood? He seems to be carried away with the spectacle of revolution, and the rhetoric he uses is emptily sloganistic :

And waving our red weapons o'er our heads, Let's all cry 'Peace, freedom, and liberty!'

The upshot of all this histrionic fervour is that Cassius immediately switches into the theatrical mode, repeating Brutus's injunction, "Stoop, Romans, stoop":

Stoop, then, and wash. How many ages hence

Shall this our lofty scene be acted over, In states unborn and accents yet unknown!

(III.1.111-13)

Is this indeed a lofty scene, an elevated subject proper to tragedy in the Senecan mode ? Indeed, as Polonius will confirm, "Seneca cannot be too heavy". 4

Brutus is caught up in his histrionic enthusiasm : 
How many times shall Caesar bleed in sport, That now on Pompey's basis lies along

No worthier than the dust!

The theatre image of Cæsar's bleeding in sport is the essence of Brutus's skewed notion of being sacrificers and not butchers. A really effective theatrical production, in Brutus's eyes, depends on the fact that "in the spirit of men there is no blood". As a final ironic note on this theme, Brutus will give Antony reasons why Cæsar was dangerous and needed to be assassinated for the good of Rome, "Or else were this a savage spectacle" (223). By Brutus's own admission then it is a spectacle, if not a savage one, rather a "lofty scene", in Cassius's euphemizing rhetoric, and Cæsar bleeds "in sport", just as in Hamlet "they do but jest, poison in jest; no offense $i$ ' th' world" (III.2.238-39).

We know pretty confidently from the account of Thomas Platter, a Swiss traveller, that Julius Casar was performed on September 21, 1599, probably at the newly constructed Globe theatre. Coming as it does right between Henry $V$ and Hamlet, Julius Casar is an odd play because it is so limited in its use of verbal and figurative resources. Hamlet is the most extravagant play in the canon for its vocabulary, with an abundance of hapax legomena, whereas Julius Caesar is among the most sparse. Shakespeare seems to be experimenting with a special Roman style in this play. Cassius's polysyllabic disclosure of his grand intentions uses an official Roman style of public pronouncements :

Now know you, Casca, I have moved already

Some certain of the noblest-minded Romans

To undergo with me an enterprise

Of honourable dangerous consequence...

An enterprise of honourable dangerous consequence is obviously something big and likely to appeal to the noblest-minded Romans. But the Roman style in this play is more typically expressed in homely, straightforward, non-figurative and monosyllabic utterances, like Brutus's declaration to a wife as dear to him as "the ruddy drops / That visit my sad heart", imagined as familiar acquaintances who happen to drop by.

The Roman style becomes most effective in the last two acts of the play when the conspirators face their inevitable deaths, using an elegiac style very similar to the compressed, pithy, Senecan style that was coming into fashion in early seventeenth century prose. The Senecan style is closely connected in Shakespeare's mind with popular Stoic ideas, especially fortitude, endurance, absolute honesty in public and private dealings, and a readiness to commit suicide rather than suffer a dishonourable captivity or figure in an enemy's triumphal procession. Shakespeare does not try to engage the contradictions in Stoic doctrine between passive endurance and an active participation in one's own heroic death. 
Brutus remembers that he "did blame Cato for the death / Which he did give himself" (V.1.101-2), before he enunciates a purely Stoic creed :

But I do find it cowardly and vile,

For fear of what might fall, so to prevent

The time of life, arming myself with patience

To stay the providence of some high powers

That govern us below.

This awkward speech lacks conviction, and he soon recants :

No, Cassius, no : think not, thou noble Roman,

That ever Brutus will go bound to Rome;

He bears too great a mind.

(V.1.110-12)

It takes a great mind not to be "contented to be led in triumph /Thorough the streets of Rome" (V.1.108-9).

The leave-taking of Cassius and Brutus at the close of this scene shows Shakespeare's elegiac Roman style at its best. The friends take their "everlasting farewell" in a grave and serious way, extremely formal, and elevated above ordinary discourse with refrain lines :

Brut. For ever, and for ever, farewell, Cassius!

If we do meet again, why, we shall smile;

If not, why then this parting was well made.

Cass. For ever, and for ever, farewell, Brutus!

If we do meet again, we'll smile indeed;

If not, 'tis true this parting was well made.

(V.1.116-21)

Although it is so impersonal, so lofty, non-figurative and even non-colloquial, it is moving nevertheless. At this stage, the beginning of the fifth act, the leaders of the conspiracy are saluting each other as if they were already marked for death. We are far from Cæsar's heroic vaunting about death earlier in the play :

Cowards die many times before their deaths;

The valiant never taste of death but once.

Of all the wonders that I yet have heard,

It seems to me most strange that men should fear,

Seeing that death, a necessary end,

Will come when it will come. 
In the final scene of the play, Brutus expresses a kind of quiet tranquillity as he seeks out his necessary death. He is fully occupied with eulogizing his inevitable Roman suicide :

I shall have glory by this losing day

More than Octavius and Mark Antony

By this vile conquest shall attain unto.

In a formal couplet, Brutus persuades Strato to hold his sword for him while he runs on it: "Cæasar, now be still; / I killed not thee with half so good a will" (V.5.50-1). Death is sought after as a positive good, and Strato asserts the essential principle of Roman suicide :

For Brutus only overcame himself,

And no man else hath honour by his death.

(V.5.56-7)

Honour is a Roman idea in this play and in Antony and Cleopatra, Coriolanus, Titus Andronicus, and The Rape of Lucrece. The stylistic expression of honour is the chief function of the Roman style : it is simple, straightforward, almost monosyllabic, grave in tone and rhythm, and without any rhetorical or figurative flourishes. The best that Antony can say for the dead Brutus is :

His life was gentle, and the elements

So mixed in him that Nature might stand up

And say to all the world, 'This was a man!'

(V.5.73-5)

By "man" Antony obviously means "Roman", and it is interesting that in Hamlet, if that indeed is Shakespeare's next play, Antony's sentiments would apply much better to Horatio than to Hamlet. Like Brutus, Horatio is the ideal Stoical man. Hamlet sees him "As one, in suff'ring all, that suffers nothing", a man "That is not passion's slave", and one who is "not a pipe for Fortune's finger / To sound what stop she please" (III.2.66, 70-2).

Hamlet cannot afford to be a Stoic like Brutus, but everywhere one turns there are surprising links between the two plays and between Hamlet and Brutus. Hamlet, too, is a bookish man, who enters reading "Words, words, words" in the scene with Polonius. Although no mention is made of a dog-eared book, he is clearly a voracious reader. Brutus's familiar book reminds us of the flow of personal and affective details that prepare us for the entrance of Cæsar's Ghost. Only Brutus and Portia are endowed with this tragic aura in a play that depends more strongly on catharsis than any tragedy yet written by Shakespeare (including some of the history plays, like Richard II). If we want to understand what Shakespeare is doing in Julius Caesar, we need only compare its sportive, gamesome, and highly political 


\section{BRUTUS'S DOG-EARED BOOK}

Antony, with the tragic hero of Antony and Cleopatra. In other words, Antony is not included in the tragic perspective of Julius Casar as Brutus and Portia are.

In order to understand Brutus, we have to see him projected against a screen of illusions in which he makes the conspiracy and the assassination of Cæsar into his own "savage spectacle". This movement is not unlike what we see of Othello, although Iago is a much more powerful catalyst than Cassius. Further, the tragedy in Julius Casar is thickened and intensified by the Roman style, which is preoccupied with death and honour and ethical issues to the exclusion of pleasure and the imagination. The whole play, especially the last two acts, envelops us in an elegiac tone in which the characters are allowed to work out their inevitable fates. The one thought that gives Brutus pleasure before he runs on his own sword is in character: .

My heart doth joy that yet in all my life

I found no man but he was true to me.

(V.5.34-5)

This kind of simple moral affirmation could only occur in one of Shakespeare's Roman plays. It is part of the homely assurance and ethical lucidity expressed by the Roman style.

Maurice CHARNEY

Rutgers University

1 Shakespearean Meanings, 1968, p. 4.

2 As seen by Decius Brutus in II.1.202 sq.

3 Measure for Measure, III.2.25.

$4 \quad$ Hamlet, II.2.407. 